
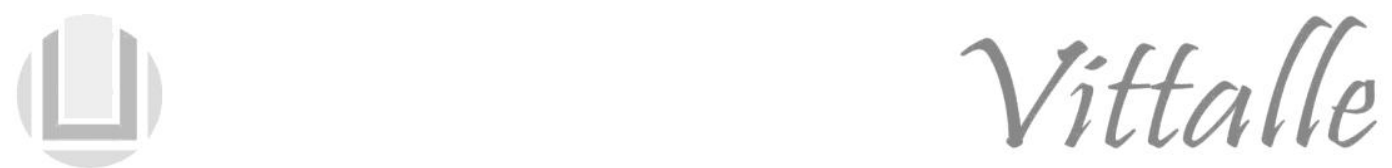

\title{
Sperm alterations in the Vesper mouse Calomys laucha exposed to soil contaminated with crude oil
}

\author{
Krissia Aparecida de Almeida, Flavio Manoel Rodrigues da Silva-Júnior ${ }^{*}$, Edariane \\ Menestrino Garcia, Ana Luiza Muccillo-Baisch
}

Laboratório de Ensaios Farmacológicos e Toxicológicos, Instituto de Ciências Biológicas, Universidade Federal do Rio Grande - FURG, Rio Grande, RS, Brazil

Histórico do Artigo Recebido em: 24/05/2018

Aceito em:

$13 / 06 / 2018$

Key words: Calomys laucha; Sperm viability; Crude oil exposure; Sperm abnormalities

Palavras-chave: Calomys laucha; Viabilidade espermática; Exposição a petróleo; Anomalias espermáticas

\begin{abstract}
Calomys laucha (small vesper mouse) is a small wild rodent that lives in the southern coastal dunes of Brazil, where it feeds and builds nests for breeding, and this lifestyle makes it susceptible to the impacts of human activities in coastal and marine regions. This study aimed to evaluate the some reproductive parameters of $C$. laucha males in a simulated oil spill. The animals were exposed for 14 days to artificial soil contaminated by petroleum in different concentrations $(0,1,2,4$ and $8 \% \mathrm{v} / \mathrm{v})$ and after this period the animals were killed and the testis and epididymis removed for analysis. Exposure did not affect the weight of the testes, but it caused a decrease in sperm viability and an increase in the presence of sperm abnormalities, in particular the "lasso-like fold" anomaly (in this case a dose-dependent effect). This study demonstrated that exposure to soil contaminated by crude oil causes damage to the spermatozoa of $C$. laucha, which may influence the fitness of populations of this species.
\end{abstract}

Alterações espermáticas no camundongo das dunas Calomys laucha exposto a solo contaminado com petróleo

\section{Introduction}

Petroleum products may account for the majority of chemicals found in contaminated sites (1). This category of contaminant is characterized by a complex mixture of organic compounds, with the majority of hydrocarbon compounds containing sulfur, nitrogen, oxygen, and metals such as nickel, vanadium, uranium and copper (2). Aromatic hydrocarbons present in petroleum cause various forms of damage, including mutagenic, carcinogenic, teratogenic (3) as well as reproductive (4).

Wild rodents have been used as biological models in the evaluation of environmental damage resulting from exposure to metals (5) and contaminants of organic origin (6-8).

\footnotetext{
* Corresponding author: f.m.r.silvajunior@gmail.com
} 
Calomys laucha Olfers 1818 is a South American rodent belonging to the family Cricetidae, which occurs in southern Bolivia, southern Brazil, Uruguay and central Argentina (9). The species is found in grasslands, agricultural areas, roadsides and coastal dunes, where the animals feed and reproduce (10).

Species of the genus Calomys are terrestrial and nocturnal, and are primarily granivorous. They build spherical nests with plant material in depressions in the soil or camouflaged among leaves or dead tree trunks. They play an important role as seed dispersers and provide food for different predators. They reproduce throughout the year although with less intensity in the winter, and they have a harem-forming behavior. They are small, weighing about $40 \mathrm{~g}$ (11), and have a life expectancy averaging 13.5 months in laboratory conditions (12).

The onset of sexual maturation in $C$. laucha females is on average at 16 days in summer and 22 days in winter, with the first heat occurring at around 23 days in the summer and 36 days in the winter in the presence of males. Gestation lasts for 21 days on average, and the average number of pups per litter is 8 in the summer and 4 in winter, with the weaning of pups occurring at about 21 days of life $(11,12)$.

C. laucha males reach sexual maturity at around 25 days of age, as evidenced by the opening of the seminiferous tubules and the presence of sperm in the germinal epithelium. Sexual maturation of males of this species also appears to be linked to the body weight of the animals. The first appearance of epididymal sperm was observed in animals weighing from 12 to $14 \mathrm{~g}$ (13).

It is extremely important to know the reproductive aspects of wildlife both in their natural habitat and in captivity, especially when the animal is a transmitter of diseasecausing organisms (14). The Vesper mouse $C$. laucha lives in proximity to anthropogenic sites and can thus be directly or indirectly exposed to contaminants such as petroleum products. Additionally, this species may be more resistant to exposure to toxins than conventional laboratory rodents because of its genetic variability and resistance to stressors (15). However, studies on the effects of soil contamination by crude oil using reproductive parameters in C. laucha are nonexistent. Thus, the aim of this study was to investigate the occurrence of changes in some reproductive parameters in wild $C$. laucha males acutely exposed to crude oil in contaminated soil.

\section{Materials and methods}

\subsection{Animals}

Wild C. laucha males (between 2 and 3 months old and 22.8 $\pm 0.5 \mathrm{~g}$ ) were obtained from the animal house of unconventional rodents of the Biological Sciences Institute at Federal University of Rio Grande-FURG. The animals were kept in standard conditions of temperature $\left(21 \pm 3{ }^{\circ} \mathrm{C}\right)$ and photoperiod (12-h light/dark). The animals were fed with commercial feed (Bio Base, Bio-Tec, Águas Frias, SC) and provided water ad libitum. The experimental protocol was approved by the Ethics Committee on Animal Use (CEUA/FURG) process 23116.005277/2011-98, 31/2011.

\subsection{Treatment}

Tropical artificial soil (TAS), consisting of $70 \%$ sand, $20 \%$ clay, and $10 \%$ organic material (coconut fiber) was used. Approximately $1 \mathrm{~kg}$ of soil was placed in the bottom of each cage $(30 \times 20 \times 15 \mathrm{~cm})$ and animals were exposed individually (one animal per cage) for 14 days without renewal of the soil. For crude oil exposure, the soil was mixed 
with Hydra light oil type (w/w). The treatments used were as follows: control $(1 \mathrm{~kg}$ TAS soil), $1 \%$ (990 g TAS + $10 \mathrm{~g}$ crude oil), $2 \%$ (980 g TAS + $20 \mathrm{~g}$ crude oil), $4 \%$ (960 g TAS + $40 \mathrm{~g}$ crude oil) and $8 \%$ (920 g TAS + $80 \mathrm{~g}$ crude oil). The sample size consisted of 6 animals per experimental treatment (16).

\subsection{Evaluated parameters}

At the end of the exposure period, the animals were anesthetized with halothane and euthanized by exsanguination; then, the testes were removed for weighing and macroscopic visualization; epididymis also was removed to use in sperm analysis. All procedures were carefully performed to avoid cell damage and followed other studies (experiments were performed in the dark and with controlled temperature) (17).

\subsubsection{Sperm cell shape abnormality}

Sperm were sampled from the cauda epididymis, placed in $1 \mathrm{ml}$ Sorensen buffer ( $\mathrm{pH} 7.0)$ and carefully centrifuged $(100 \mathrm{~g}, 5 \mathrm{~min})$ to obtain a pellet of undamaged cells. This pellet was re-suspended in $1 \mathrm{ml}$ Sorensen buffer and smear preparations were made on clean slides, air dried, and fixed in absolute methanol for $10 \mathrm{~min}$. After drying, the slides were immersed in a $10 \%$ Giemsa stain for $1 \mathrm{~h}$ in the oven $\left(\sim 32{ }^{\circ} \mathrm{C}\right)$. A total of 1,000 sperm per animal were analyzed for the following morphological changes: head abnormalities, two tails and lasso-like fold (16).

2.3.2 Sperm viability by $\mathrm{mtt}$ (3-(4,5-dimethylthiazol-2-yl)-2,5-diphenyltetrazolium bromide) assay

Other portions of the epididymis were removed and the spermatic content was placed in $5 \mathrm{ml}$ PBS (phosphate buffered saline) and re-suspended. Then, in the dark, $50 \mu \mathrm{L}$ cell suspension was added to $25 \mu \mathrm{l}$ MTT reagent $(5 \mathrm{mg} / \mathrm{ml}$ in PBS) in sterile 96-well microplates, in triplicate, and incubated at $37^{\circ} \mathrm{C}$ for $30 \mathrm{~min}$. Thereafter, $200 \mu \mathrm{DMSO}$ (dimethyl sulfoxide) was added to each well to dissolve the formazan crystals formed during the reaction. The negative control was only mixed with $200 \mu \mathrm{l}$ DMSO, in triplicate. The absorbance was read using a wavelength of $490 \mathrm{~nm}$ (18). Data were processed by considering average absorbance values relative to the negative control.

\subsection{Data analysis}

The results were expressed as the mean \pm standard error. Means were compared by analysis of variance (ANOVA), followed by a posteriori Fischer tests for comparisons between groups, using a level of significance at 0.05 .

\section{Results and discussion}

There was no statistically significant difference in the weight of the testes of animals exposed to different concentrations of crude oil in the soil (Figure 1). In a previous study, Da Silva-Junior et al. (6) showed similar results in the Algerian mouse Mus spretus exposed to oil. On the other hand, these data differed from the results reported by Orisakwe et al. (19) where male albino rats were exposed to different doses of crude oil dissolved in Tween 80 in drinking water for 7 days. The treatment with the crude oil showed a dose-dependent decrease in the absolute weight of the testicles. The route of administration may be a crucial factor for the differences found in this study. 


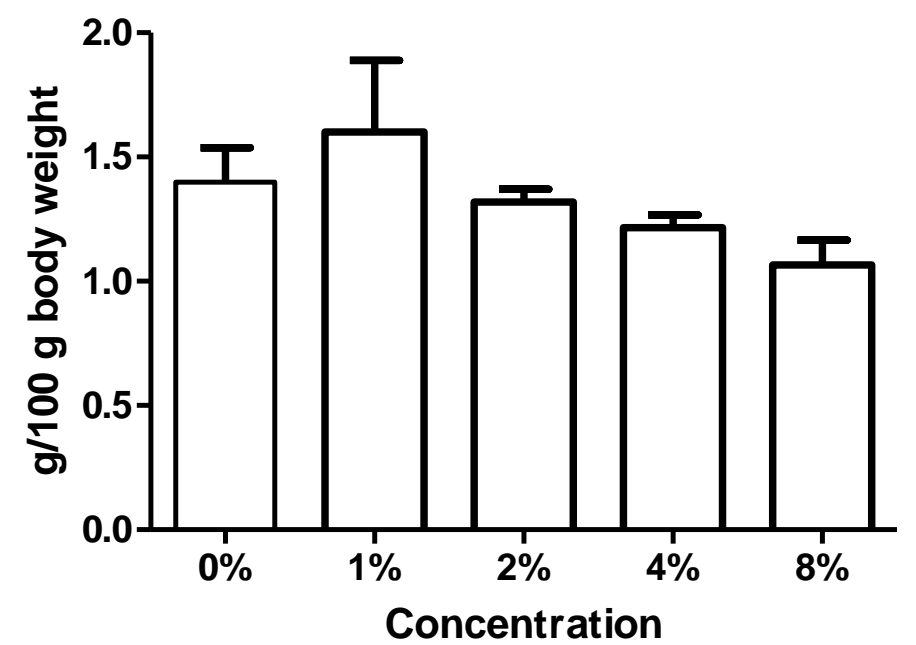

Figure 1: Weight in grams of the testis per 100 grams of body weight of C. laucha exposed to crude oil by 14 days.

Sperm viability as determined by MTT assay was significantly reduced in animals exposed to contaminated soil containing $2 \%$ oil compared to the other treatments. In this case, the response does not appear to be dose-dependent (Figure 2). Many substances are recognized worldwide as being endocrine disruptors (EDs), for example the oil-derived substances bisphenol A, benz[a]anthracene and benzo[a]pyrene. Many EDs have various effects at different levels, and the effects observed at low doses are observed occur at high doses (20). Wang et al. (21) investigated the reproductive toxicity induced by organic extracts from petrochemical wastewater in rats and found that sperm viability decreased $(\mathrm{p}<0.01)$, suggesting that rat testicular cells can be useful for predicting potential reproductive toxicity of organic extracts in petrochemical effluents.

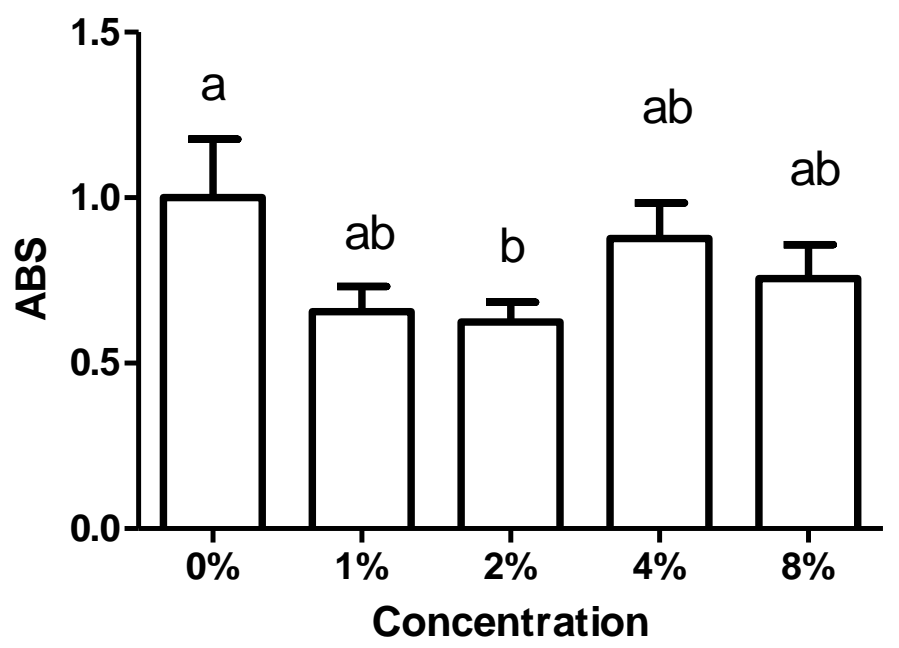

Figure 2: Sperm viability as determined by absorbance (ABS) of MTT assay of C. laucha exposed to crude oil by 14 days. Difference between the letters represents a statistical difference between the groups $(\mathrm{p}<0.05)$

Induction of sperm morphological abnormalities has been proposed as a rapid test for carcinogenic activity (22). In the present assay, there was a decrease in the percentage of normal sperm at the crude oil concentrations of 2, 4, and 8\% (Table 1). Furthermore, the "lasso-like fold" type sperm abnormality was the most frequently observed following exposure to crude oil (Table 1). 
Table 1: Percentage of normal sperm cells or different types of abnormality.

\begin{tabular}{ccccc}
\hline Treatment & Normal & Lasso-like fold & Two tails & Head abnormalities \\
\hline $0 \%$ & $99.4 \pm 0.2 \mathrm{a}$ & $0.6 \pm 0.2^{\mathrm{a}}$ & $0 \mathrm{a}$ & $0 \mathrm{a}$ \\
$1 \%$ & $92.1 \pm 5.8 \mathrm{a}$ & $7.6 \pm 5.7^{\mathrm{a}}$ & $0 \mathrm{a}$ & $0.3 \pm 0.2 \mathrm{a}$ \\
$2 \%$ & $80.7 \pm 3.3 \mathrm{~b}$ & $19.1 \pm 3.3 \mathrm{~b}$ & $0 \mathrm{a}$ & $0.2 \pm 0.1 \mathrm{a}$ \\
$4 \%$ & $69.2 \pm 7.8 \mathrm{c}$ & $29.5 \pm 7.9 \mathrm{c}$ & $0.1 \pm 0.1 \mathrm{~b}$ & $1.2 \pm 0.4 \mathrm{~b}$ \\
$8 \%$ & $51.5 \pm 4.9 \mathrm{~d}$ & $46.4 \pm 6.2 \mathrm{~d}$ & $0.0 \pm 0.1 \mathrm{ab}$ & $2.1 \pm 1.4 \mathrm{~b}$
\end{tabular}

Different letters in the same column indicate significant difference $(\mathrm{p}<0.05)$

Sperm abnormalities, including the two-tail type and head anomalies, were observed in animals exposed to the two highest concentrations (4 and 8\% crude oil) (Table 1). A study using CD-1 mice showed that a concentration of $9.4 \mathrm{mg} / \mathrm{kg}$ of vanadium administered intraperitoneally for 60 days caused a similar percentage of sperm abnormalities such as folding (23). Silva-Junior et al. (16) evaluated the effects of exposure to soil contaminated with oil on sperm morphology in the wild mouse Mus spretus. The frequency of banana and hook abnormalities was also higher in mice exposed to the contaminated soil. However, the frequency of sperm with two tails or amorphous head was similar between the control mice and mice exposed to oil, results that differ from those of the present study. Also, the physicochemical characteristics of the contaminant should be considered in toxicity at the cellular level. For example, other studies point to toxicity in the formation of gametes by hydrophobic substances (oily substances) (24).

Although limited, there are some studies that have evaluated the reproductive activity of C. laucha. Vilela et al. (8) found that administration of bisphenol A (BPA) in utero to C. laucha females resulted in altered sperm parameters of their male offspring, notably sperm motility, acrosome integrity, membrane integrity and sperm morphology. Corcini et al. (25) aimed to evaluate in vitro the quality of sperm in C. laucha by testing for improvements in the in vitro penetration test (IVP). In turn, Heppe-Lopes et al. (26) showed that the addition of copper to the drinking water caused significant changes in morphology, membrane integrity, and sperm acrosome of C. laucha, but without affecting their fertilizing capacity in vitro. However, studies on the effects of oil exposure on sperm abnormalities in $C$. laucha are non-existent.

\section{Conclusion}

In this study, we simulated the occurrence of an oil spill in a typical $C$. laucha habitat (soil) in order to mimic how the animal might come into contact with this contaminant, via uptake pathways through the skin, by inhalation and by geophagy. This exposure resulted in injuries to the germ cells, which may have negative effects on reproductive performance and therefore undermine the size and structure of the population. These results contribute to a better understanding of the damage caused in wild rodents by exposure to crude oil, a major contaminant in coastal areas and urbanized regions. Finally, $C$. laucha proves to be a good model for predicting the biological impacts of oil spills in the coastal zone/interface marine environment where it is typically found. This study also provides evidence that small mammals such as C. laucha are useful in monitoring human-mediated environmental damage. 
K. A. de Almeida et al./ Vittalle v. 30, n. 2 (2018) 31-37

\section{Acknowledgments}

The authors thank the Coordenação de Aperfeiçoamento de Pessoal de Nivel Superior, CAPES, for the Master scholarship.

Conflict of Interest: All the authors declare that they have no conflict of interest.

\section{References}

1. Burgess LC. Organic pollutants in soil. In: Brevik, E.C., Burgess, L.C. (Eds.), Soils and Human Health. CRC Press, Boca Raton, Florida, USA. 2013. p. 83-106.

2. Nadim FN, Hoag GE, Liu S, Carley RJ, Zack P. Detection and remediation of soil and aquifer systems contaminated with petroleum products: an overview. J Petrol Sci Eng 2000; 26:169-178.

3. Kayal S, Connell DW. Polycyclic aromatic hydrocarbons in biota from the Brisbane River Estuary, Australia. Estuar Coast Shelf S 1995; 40:475-493.

4. Feuston MH, Hamilton CE; Schreiner CA, Mackerer CR. Developmental toxicity of dermally applied crude oil in rats. J Environ Sci Heal A 1997; 52:79-93.

5. Tapisso JT, Marques CC, Mathias ML, Ramalhinho MG. Induction of micronuclei and sister chromatid exchange in bone-marrow cells and abnormalities in sperm of Algerian mice (Mus spretus) exposed to cadmium, lead and zinc. Mutat Res 2009; 678:59-64.

6. Da Silva-Júnior FMR, Monarca RI, Dias D, Ramalhinho MG, Mathias MM, Muccillo-Baisch AL. Physiological damage in Algerian mouse Mus spretus (Rodentia, Muridae) exposed to crude oil. J BioSci Biotech 2012; 1:125-133.

7. Da Silva-Júnior FMR, De Almeida KA, Silva PF, Muccillo-Baisch AL. Hematological profile as a crude oil exposure-related marker in wild rodent. J BioSci Biotech 2013; 2:89-94.

8. Vilela J, Hartmann A, Silva EF, Cardoso T, Corcini CD, Varela-Junior AS, Martinez PE, Colares EP. Sperm impairments in adult vesper mice (Calomys laucha) caused by in utero exposure to bisphenol A. Andrologia 2014; 46: 971-978.

9. Nowack RM, Paradiso J. Walker's Mammals of the World. 4th ed. John Hopkins University Press, Baltimore. 1983.

10. Reis NR, Peracchi AL, Pedro WA, Lima IP. Mamíferos do Brasil. Londrina: Universidade Estadual de Londrina, 2006.

11. Cittadino EA, Carli PDE, Busch M, Kravetz FO. Effects of food supplementation on rodents in winter. J Mammal 1994; 75:446-453.

12. Hodara VL, Espinosa MB, Merani MS, Quintans C. 1989. Calomys laucha (Rodentia, Cricetidae): Growth and breeding in laboratory conditions. Lab Anim 1989; 23:340-344.

13. Pederassi GC. Desenvolvimento sexual de Calomys laucha (Rodentia: Muridae) macho durante a puberdade. Dissertação. undação Universidade Federal do Rio Grande. 2005.

14. Doyle TJ, Bryan RT, Peters CJ. Viral hemorrhagic fevers and hantavirus infections in the Americas. Emerg Infect Dis 1998; 12:95-110.

15. Vandenbergh JG. 2004. Animal models and studies of in utero endocrine disruptor effects. ILAR J 2004; 45:438-442.

16. Da Silva-Júnior FMR, Monarca RI, Dias D, Ramalhinho, MG, Mathias, MM, Muccillo-Baisch A. L. Geno- and cyto-toxicity in free-living rodent Mus spretus exposed to simulated onshore oil spill. B Environ Contam Tox 2013; 91:465-468.

17. Farcas MT, Kisin ER., Menas,AL, Gutkin DW, Star A., Reiner RS, Shvedova AA. Pulmonary exposure to cellulose nanocrystals caused deleterious effects to reproductive system in male mice. $\mathrm{J}$ Environ Sci Heal A 2016; 79(21), 984-997.

18. Nasr-Esfahani MH, Aboutorabi R, Esfandiari E, Mardani M. Sperm MTT viability assay: a new method for evaluation of human sperm viability. J Assist Rep Genet 2002; 19:477-482.

19. Orisakwe OB, Akumka DD, Njan AA. Testicular toxicity of Nigerian bonny light crude oil in male albino rats. Reprod Toxicol 2004;18:439-442.

20. Vandenberg LN, Maffini MV, Beverly SC, Rubin S, Soto AM. Bisphenol-A and the great divide: A 
review of controversies in the field of endocrine disruption. Endocrinol Vertebr 2009; 30:75-95.

21. Wang X, Shi W, Wu J, Hao Y, Hu G, Liu H, Han X, Yu H. Reproductive toxicity of organic extracts from petrochemical plant effluents discharged to the Yangtze River, China. J Environ Sci 2010; 22:297-303.

22. Wyrobek AJ, Bruce WR. Chemical induction of sperm abnormalities in mice. P Natl Acad Sci 1975; 72:4425-4429.

23. Aragón AM, Altamirano-Lozano M. Sperm and testicular modifications induced by subchronic treatments with vanadium (IV) in CD-1 mice. Reprod Toxicol 2011; 15:145-151

24. Mishra V, Saxena DK, Das, M. Effect of argemone oil and argemone alkaloid, sanguinarine on Sertoli-germ cell coculture. Toxicol Let 2009; 186(2): 104-110.

25. Corcini CD, Stephan MHL, Colares EP, Santos ECS, Varela AS, Bongalhardo DC, Lucia T. 2012. In vitro assays for vesper mice (Calomys laucha) sperm using heterologous substrates from nonrodent species. J Exp Zool A 2012; 317:96-102.

26. Heppe-Lopes M. Effects of copper exposure via drinking water on sperm quality in the sand dune mouse Calomys laucha Olfers, 1818 (Rodentia: Muridae). Tesis, Universidade Federal do Rio Grande. 2011 